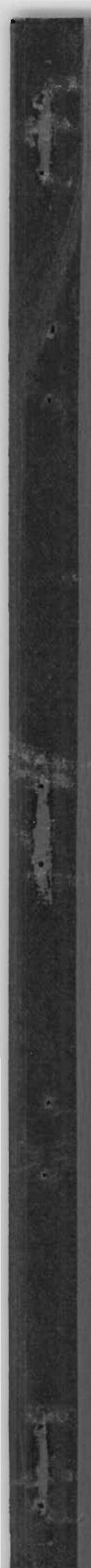

\title{
ENVIRONMENTAL TESTS OF CANDIDATE MATERIALS \\ FOR THE HIGH TEMPERATURE LATTICE TEST REACTOR
}

JUNE, 1965

REPORT

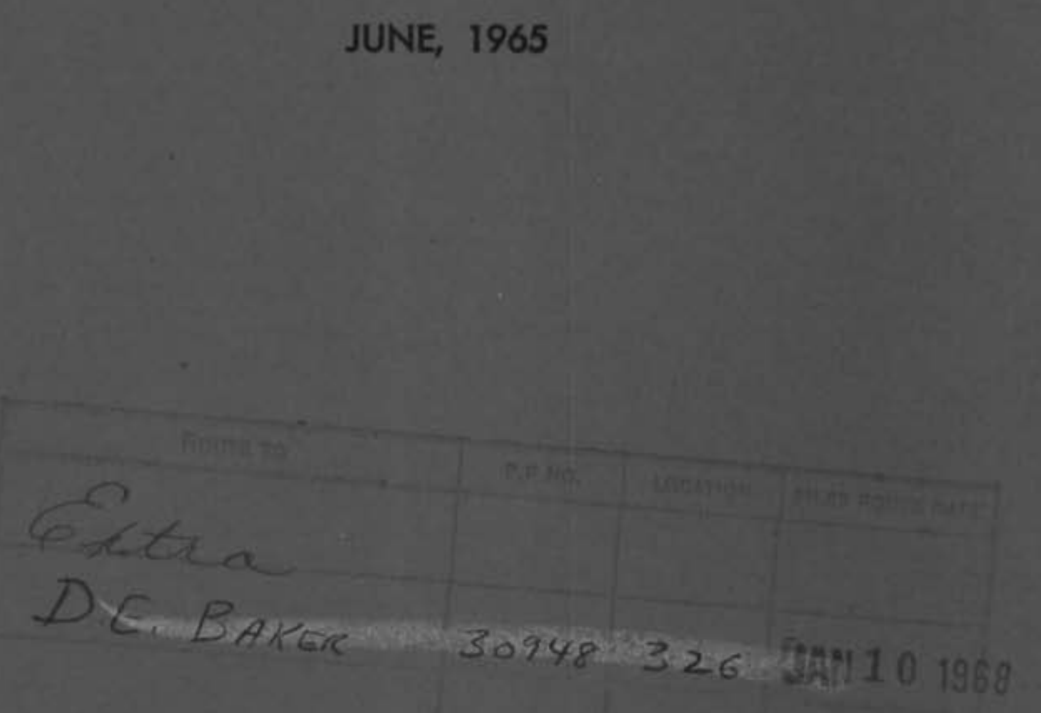

PACIFIC NORTHWEST LABORATORY operated by BATTELLE MEMORIAL INSTITUTE 


\section{LEGAL NOTICE}

This report was prepared as an account of Government sponsored work. Neither the United States, nor the Commission, nor any person acting on behalf of the Commission:

A. Makes any warranty or representation, expressed or implied, with respect to the accuracy, completeness, or usefulness of the information contained in this report, or that the use of any information, apparatus, method, or process disclosed in this report may not infringe privately owned rights; or

B. Assumes any liabilities with respect to the use of, or for damages resulting from the use of any information, apparatus, method, or process disclosed in this report.

As used in the above, "person acting on behalf of the Commission" includes any employee or contractor of the Commission, or employee of such contractor; to the extent that such employee or contractor of the Commission, or employee of such contractor prepares, disseminates, or provides access to, any information pursuant to his employment or contract with the Commission, or his employment with such contractor.

\section{PACIFIC NORTHWEST LABORATORY}

RICHLAND, WASHINGTON

operated by

BATTELLE MEMORIAL INSTITUTE

for the

UNITED STATES ATOMIC ENERGY COMMISSION UNDER CONTRACT AT(45-1)-1830 
BNWL-92

UC-40, Radiation Effects on Materials

\section{ENVIRONMENTAL TESTS OF CANDIDA TE MATERIALS} FOR THE HIGH TEMPERATURE LATTICE TEST REACTOR

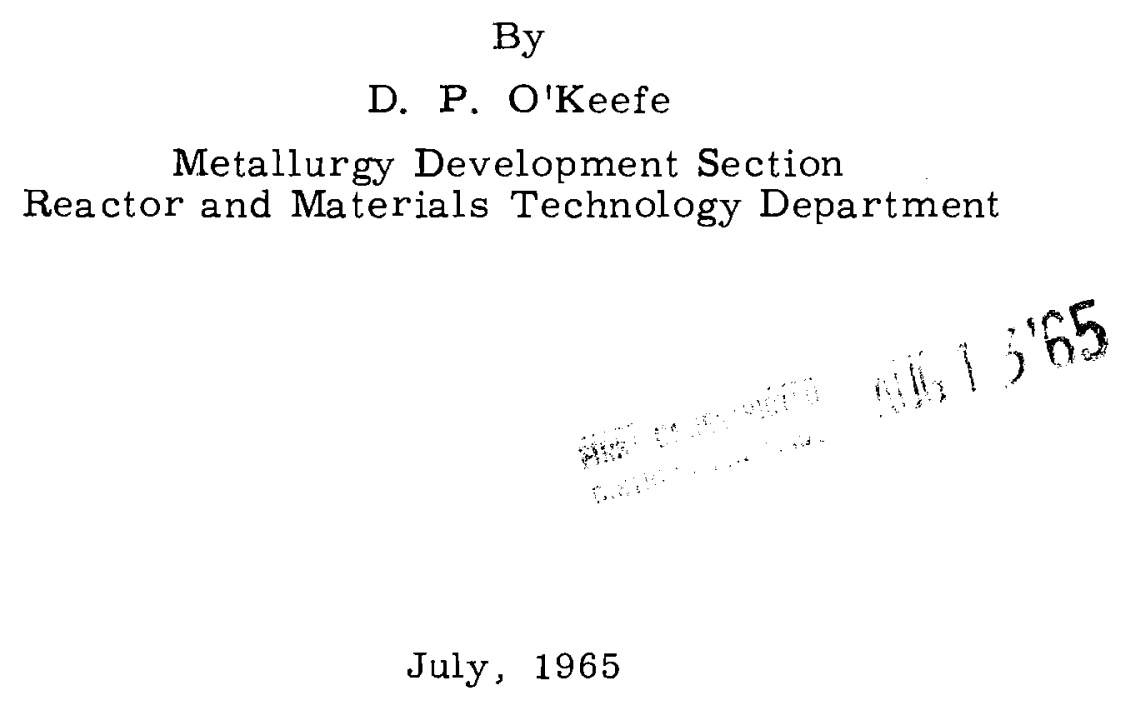

PACIFIC NORTHWEST LABORATORY RICHLAND, WASHINGTON 
Printed in USA. Price \$2.00. Available from the Clearinghouse for Federal Scientific and Technical Information National Bureau of Standards

U.S. Department of Commerce Springfield, Virginia 


\section{ENVIRONMENTAL TESTS OF CANDIDATE MATERIALS \\ FOR THE HIGH TEMPERATURE LATTICE TEST REACTOR}

\section{INTRODUCTION}

This report describes the first environmental test results relative to some of the common high temperature alloys which are under consideration for use in the High Temperature Lattice Test Reactor (HTLTR). The test program, which is continuing, also included compatibility evaluations of fuel, control, and spacer materials.

Essentially, the HTLTR is a $10 \mathrm{ft}$ cube of graphite containing channels for fuel and control devices. Surrounded by ceramic insulation, the graphite is heated electrically with graphite resistance elements. The operating temperature limit is $1000^{\circ} \mathrm{C}$, but it is desirable to extend this limit to $1200{ }^{\circ} \mathrm{C}$.

At peak operating conditions, the reactor creates a severe environment for metallic components such as fuel cladding, control rods, safety blades, brick hangers, and piping. A $10,000 \mathrm{hr}$ life at $1000{ }^{\circ} \mathrm{C}$ is required of these components. A.lthough the neutron flux is insignificantly low, the chemistry of the environment creates problems with materials. Since a nitrogen atmosphere will be maintained throughout the graphite and insulation, oxygen, which inevitably will be present as a contaminant, will react with the graphite to form carbon monoxide at the operating temperature. Most of the high temperature alloys, which depend on chromium for corrosion resistance, will be subject to some degree of carburization and nitriding. Furthermore, in the reducing atmosphere, there are possibilities of reactions between alloys and other materials such as $\mathrm{UO}_{2}, \mathrm{~B}_{4} \mathrm{C}$, and the refractory brick. Because of the available water on and in construction materials such as refractory brick, the water content of the atmosphere may be an important factor early in the life of the reactor. The effect of a few hundred ppm $\mathrm{H}_{2} \mathrm{O}$ in the atmosphere on the stability of materials such as $\mathrm{B}_{4} \mathrm{C}$ may influence the design of control hardware. 
BNWL-92

\section{SUMMARY}

A series of screening tests established that definite problems would exist with the use of some alloys, and permitted a selection of materials for later and more detailed testing. Candidate cladding, structural, control, and fuel materials were evaluated on the bases of weight gain, metallographic change, and room temperature mechanical properties. Test specimens were exposed in a simulated HTLTR environment for various periods up to $840 \mathrm{hr}$ in a nitrogen-graphite environment at 1000 or $1200{ }^{\circ} \mathrm{C}$.

The most pronounced effect on metallic specimens was carburization of alloys containing carbide formers. TD Nickel and Nickel 200 showed the least effects. Hastelloy B and Inconel 600 displayed limited serviceability, and were more stable than nickel when in contact with the refractory brick which will be used for insulation in the reactor. Embrittlement occurred in Hastelloy X, Inconel 625, Molybdenum, and Hastelloy X with commercially applied coatings of aluminum and ceramic.

Reactions between granulated $\mathrm{B}_{4} \mathrm{C}$ and nickel and powdered $\mathrm{UO}_{2}$ and nickel resulted in low melting alloys which melted during exposure. Massive $\mathrm{B}_{4} \mathrm{C}$ and powdered $\mathrm{UO}_{2}$ did not react with $\mathrm{TD}$ Nickel cladding in other tests. Aluminumnitride was found to be stable, but boron nitride decomposed in the simulated reactor environment.

TEST PROCEDURES

The initial screening tests for the candidate structural and cladding alloys were based on 200-hr exposures in a simulated reactor environment. Selected alloys were then tested for longer periods and their compatibility with fuel and control materials was investigated. The first $200 \mathrm{hr}$ test was at $1000{ }^{\circ} \mathrm{C}$, and subsequent exposures were at $1200^{\circ} \mathrm{C}$.

Prepurified nitrogen was passed through a graphite baffle, then over specimens held in graphite racks and finally over specimens held either in metal racks or ceramic racks made from the refractor y brick used in the reactor. To compare the effect of the atmosphe re alone and the effect of contact or close proximity to graphite, all of the components were in one 
container and all were run at the same temperature. Nitrogen and carbon monoxide were the reactive components of the atmosphere at the test temperature of 1000 and $1200^{\circ} \mathrm{C}$. For the production of carbon monoxide, oxygen was available as an impurity $(5 \mathrm{ppm})$ in the nitrogen, as adsorbed air on the container and components, and from reduced oxides.

For each test, the chamber (Figure 1) was welded closed and flushed with flowing nitrogen for at least an hour before heating. A nitrogen flow rate of approximately $0.5 \mathrm{CFH}$ through the container was maintained throughout the test. After exposure to the simulated HTLTR environment, the test materials were evaluated on the bases of weight gain,

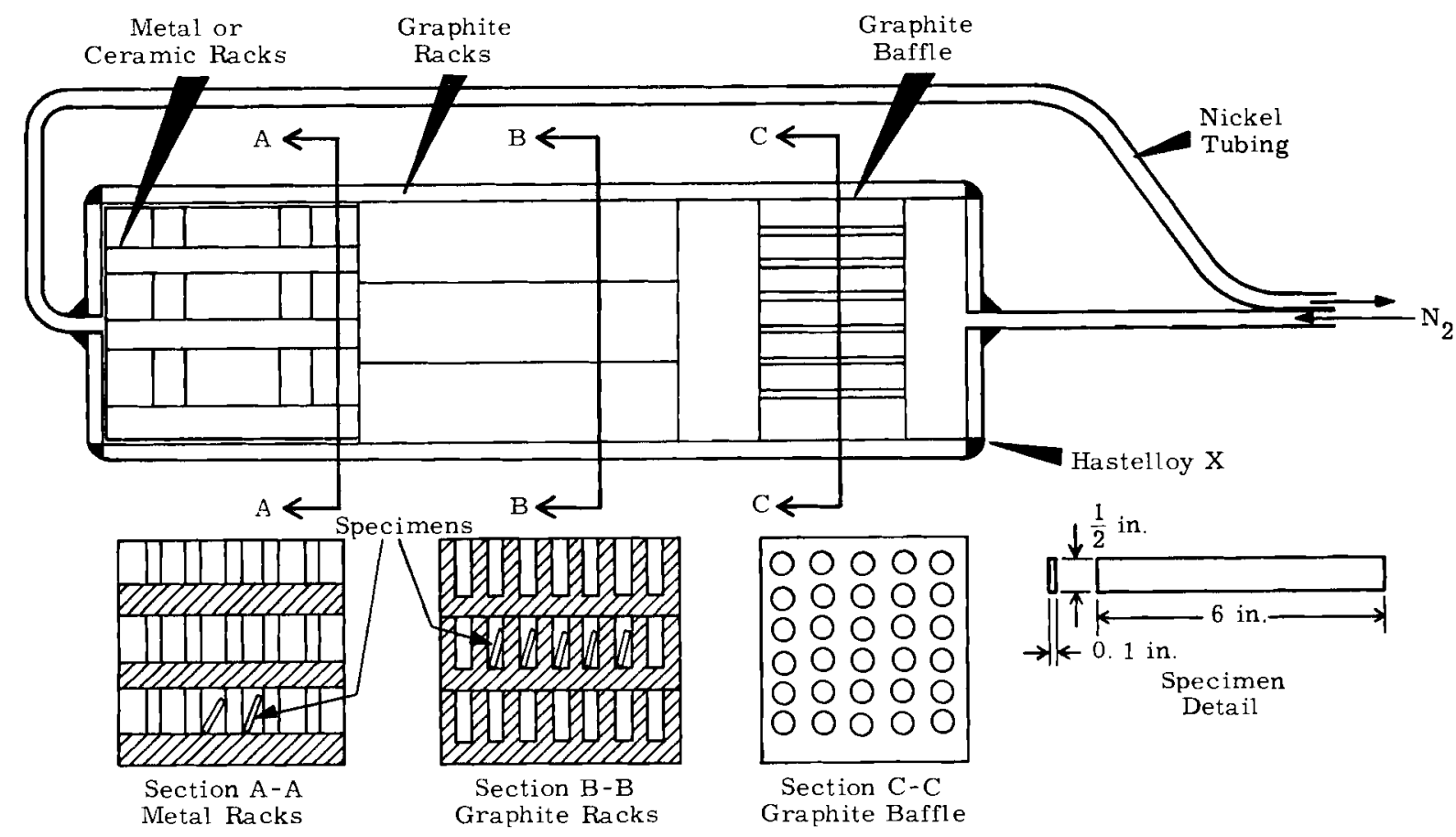

FIGURE 1

Exposure Chamber

metallographic change and room temperature mechanical properties. Bend tests were used as a primary measure of the effect of exposure on ductility. The test coupons (Figure 1) were loaded at the midpoint as a simple beam. In general, they broke with a minor deflection $\left(<20^{\circ}\right)$ or bent $180^{\circ}$. The test results (Tables III and IV, pp. 10-11) were correspondingly listed as "N" 
for the brittle ones and " $G$ " for the ductile specimens. Tensile data was also obtained primarily to evaluate ductility and give a qualitative indication of adverse exposure effects.

As a preliminary check on compatibility between materials, specimens were exposed in racks (Figure 1) constructed of the K-23 refractory brick which is intended for use as insulation and will contact some metal structural and control members. In some of the screening tests, containers of nickel, TD nickel, or graphite holding fuel and control materials were also exposed simultaneously with the other materials.

The following alloys were tested:

$\begin{array}{ll}\text { TD Nickel } & \mathrm{Ni}, 2 \mathrm{ThO}_{2} \\ \text { Nickel } 200 & 99.5 \mathrm{Ni} \\ \text { Hastelloy B } & 65 \mathrm{Ni}, 28 \mathrm{Mo}, 5 \mathrm{Fe} \\ \text { Hastelloy X } & 45 \mathrm{Ni}, 22 \mathrm{Cr}, 18 \mathrm{Fe}, \\ & 9 \mathrm{Mo}, 2 \mathrm{Co}, 1 \mathrm{~W} \\ \text { Inconel } 625 & 61 \mathrm{Ni}, 22 \mathrm{Cr}, 18 \mathrm{Fe}, \\ & 9 \mathrm{Mo}, 2 \mathrm{Co}, 1 \mathrm{~W} \\ \text { Inconel } 600 & 72 \mathrm{Ni}, 14 \mathrm{Cr}, 6 \mathrm{Fe} \\ \text { Molybdenum } & \text { Molybdenum } \\ \text { Hastelloy X-Gd } & \text { Gadolinium added (<1\%) } \\ \text { Protective Coatings } & \text { Solar S10-33A (Aluminum) } \\ \text { on Hastelloy X } & \text { Solarmic } 56100 \text { (Ceramic) } \\ & \text { Arthur Tickle Aluminized }\end{array}$

The following materials were checked for stability and compatibility with container materials.

- Fuel: $\mathrm{UO}_{2}$ in the powder and consolidated form in TD Nickel, nickel, and graphite containers

- Control: $\mathrm{B}_{4} \mathrm{C}$ as powder and in the consolidated form in TD Nickel, nickel and graphite containers

- Control: Boron nitride in TD Nickel and graphite containers

- Spacer: Aluminum nitride in graphite containers. 


\section{TEST RESULTS}

The following four tests were conducted to assess the compatibility of various alloys with the rather unique environment of the HTLTR.

(1) $200 \mathrm{hr}$ at $1000^{\circ} \mathrm{C}$

(2) $200 \mathrm{hr}$ at $1200^{\circ} \mathrm{C}$

(3) $75 \mathrm{hr}$ at $1200^{\circ} \mathrm{C}$

(4) $840 \mathrm{hr}$ at $1200^{\circ} \mathrm{C}$.

Generated within the test chamber, a corrodent caused failure of the effluent gas line and prematurely ended the attempts of Tests 3 and 4 to run for $1000 \mathrm{hr}$. However, the specimens were not affected, and useable data were obtained.

Weight change data are shown in Tables I and II, and mechanical properties in Tables III and IV. * The most significant metallographic results are shown in Figures 2 through 15 . ***

The weight change and metallographic data indicate carburization as the most strongly marked exposure effect. In all respects, specimens in contact with graphite underwent greater changes than companion specimens held in the metal racks a few inches away from the graphite. Alloys with high chromium contents were least resistant to change. Nickel 200 and TD Nickel were least affected by the simulated reactor conditions, except when in close proximity to the refractory brick. A brief description of the principal effects of the high temperature $\mathrm{N}_{2}$-graphite environment on the individual test materials follows.

TD Nickel, Nickel

These materials, when in contact with graphite at $1200{ }^{\circ} \mathrm{C}$, took on carbon to approximately the extent of the solubility of nickel for carbon $(0.4 \%)$ at this temperature. At room temperature this carbon exists as graphite nodules within the nickel matrix. Room temperature mechanical properties were not seriously reduced. These materials reacted with the

* Tables I-IV begin on p. 8.

*** Figures $2-15$ begin on $p .12$. 
$\mathrm{K}-23 \mathrm{brick}$ in the $1200{ }^{\circ} \mathrm{C}$ reducing atmosphere, resulting in an alloy which started to melt at the test temperature of $1200{ }^{\circ} \mathrm{C}$ (Figure 4). Additional test results involving nickel are described below with the fuel and control material results.

\section{Hastelloy B}

This alloy was not seriously affected by the reactor atmosphere at 1000 or $1200^{\circ} \mathrm{C}$ in $200 \mathrm{hr}$. In a longer test $(840 \mathrm{hr})$ at $1200^{\circ} \mathrm{C}$, the Hastelloy B specimens were embrittled, apparently by carburization of the molybdenum contained in the alloy. The alloy did not react with the K-23 brick.

\section{Hastelloy X, Inconel 625}

These materials were embrittled and lost strength after 200-hr exposures to the simulated reactor environment both at 1000 and $1200{ }^{\circ} \mathrm{C}$. The important reaction appeared to be carburization. Weight gain and metallographic results (Figure 7 and 8 ) indicated a more pronounced reaction in specimens in contact with the graphite. The Hastelloy $\mathrm{X}$ with gadolinium, which was tested because of its possible use as a control material, performed the same as the commercial alloy.

\section{Inconel 600}

This alloy became embrittled and lost strength when exposed in contact with the graphite. Specimens retained most of their strength and ductility when held in metal or ceramic racks a few inches away from the graphite.

\section{Molybdenum}

Exposure in contact with graphite at $1200^{\circ} \mathrm{C}$ resulted in a surface layer of carbide. Recrystallization occurred during the $1000^{\circ} \mathrm{C}$ exposure, and considerable grain growth resulted from the $200 \mathrm{hr}$ exposure at $1200{ }^{\circ} \mathrm{C}$. The grain growth and possibly the surface carbide contributed to a pronounced reduction in strength and ductility after the $1200^{\circ} \mathrm{C}$ exposure. 


\section{Coatings}

Two vendor-applied commercial aluminum coatings and one ceramic coating were tested as protection for Hastelloy $\mathrm{X}$. They failed to prevent embrittlement of the base metal in a $75 \mathrm{hr}$ test at $1200{ }^{\circ} \mathrm{C}$. Metallographic results (Figure 11) indicate that the aluminum coatings may have retarded carburization somewhat more than the ceramic coating.

\section{Uranium Oxide}

This fuel material will be contained either in graphite or metal containers. With nickel or TD Nickel as the favored metallic cladding material, a test was run to assess the compatibility of $\mathrm{UO}_{2}$ and nickel. Nickel capsules fabricated from $1 / 4$ in. tubing were filled with $\mathrm{UO}_{2}$ powder and closed either with loose plugs which would allow entry of the test atmosphere or by beam welding in a vacuum. In a $75 \mathrm{hr}, 1200{ }^{\circ} \mathrm{C}$ exposure of these two capsules, a reaction occurred between the $\mathrm{UO}_{2}$ and nickel in the unsealed capsule, producing an alloy which melted at the test temperature (Figure 14). No reaction occurred in the sealed capsule. Subsequent tests of consolidated $\mathrm{UO}_{2}$ held in an unsealed $\mathrm{TD}$ Nickel container and powdered $\mathrm{UO}_{2}$ in a sealed TD Nickel container showed no evidence of interaction.

\section{Boron Carbide}

One contemplated use for this material was in a collimator tube in which either powdered or massive $\mathrm{B}_{4} \mathrm{C}$ would be contained in a metal container. A compatibility test including two nickel containers of granulated $\mathrm{B}_{4} \mathrm{C}$, one sealed and the other open to the atmosphere, was run at $1200{ }^{\circ} \mathrm{C}$ and resulted in melt down of both capsules. The low melting alloy which was formed is shown in Figure 15. On the other hand, consolidated $\mathrm{B}_{4} \mathrm{C}$ exposed in contact with TD Nickel gave no reaction at $1200^{\circ} \mathrm{C}$.

\section{Boron Nitride}

As can be seen from the weight change data in Table II, boron nitride is not stable at the maximum operating temperature.

\section{Aluminum Nitride}

This material, which is to be used as a neutron absorber in some tests because of its nitrogen content, was nominally stable (Table II) at $1200{ }^{\circ} \mathrm{C}$. 
TABLE I

WEIGHT GAIN DATA FOR METAL SPECIMENS

Weight Gain, $\mathrm{mg} / \mathrm{dm}^{2}$

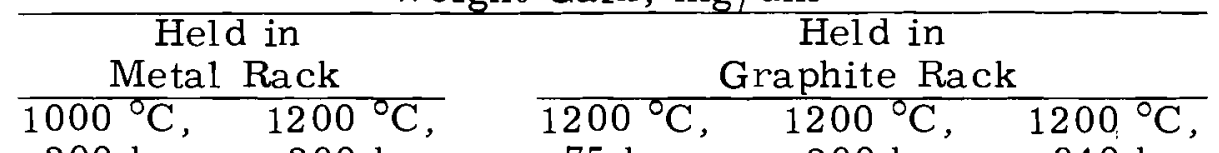

Material

Nickel

TD Nickel

Hastelloy B

Molybdenum

Inconel 600

Inconel 625

Hastelloy $\mathrm{X}$

Hastelloy X-

Arthur Tickle

Aluminized

Hastelloy X-

Solar

Aluminized

Hastell oy X-

Solar S6 100

Coating

$200 \mathrm{hr} \quad 200 \mathrm{hr}$

500

600

800

200

300

600

1200

400

900

170

26

450

360

240

1400

$-$

-
190

400

500

1800

300

500

1660

400

- $\quad 3200$

2400 
TABLE II

WEIGHT CHANGE DATA FOR CERAMIC SPECIMENS

$\mathrm{UO}_{2}$, Massive, in Unsealed

TD Ni Container

$75 \mathrm{hr}$

Weight

Specimen

Change,

Size, $g$

$\%$

$840 \mathrm{hr}$

Weight

Change,

26.50

$-0.34$

$\mathrm{UO}_{2}$, Massive, in Graphite

$-0.44$

$\mathrm{UO}_{2}$, Powder, in Unsealed

Nickel Container

melted

$\mathrm{UO}_{2}$, Powder, in Evacuated

and Sealed Ni Container

8. 18

$+0.24$

$\mathrm{UO}_{2}$, Powder, in Unsealed

Graphite Conta iner

8. 96

$-0.11$

$-0.67$

$\mathrm{B}_{4} \mathrm{C}$, Massive, in Unsealed TD Ni Container

$+0.6$

$\mathrm{B}_{4} \mathrm{C}$, Massive, in Unsealed Graphite Container

1. 68

$+0.6$

$\mathrm{B}_{4} \mathrm{C}$, Powder, in Graphite

Container

6.58

$-0,15$

$-0.15$

$\mathrm{B}_{4} \mathrm{C}$, Powder, in Unsealed

$\mathrm{Ni}$ Container

- $\quad$ melted

$\mathrm{B}_{4} \mathrm{C}$, Powder, in Evacuated and Sealed Ni Container

- melted

BN, Massive, TD Ni Can

5. 92

$-3.04$

BN, Massive, Graphite Can

6. 75

$-0.74$

$-1.93$

$B N$, Massive, No Container

6. 88

$-1.3$

$-1.74$

BN, Massive, on Ceramic

Rack

6. 85

$-8.5$

AlN, Massive, Graphite

Can

6.38

$+0.3$

+0. 15

All specimens with the exception of one boron nitride specimen as noted were held in graphite racks. 
TABLE III

PROPERTIES AFTER $200 \mathrm{hr}$ EXPOSURE IN CONTACT WITH GRAPHITE (HELD IN GRAPHITE RACKS)

\begin{tabular}{|c|c|c|c|c|c|c|}
\hline & Exposure & $\begin{array}{l}\text { Tensile } \\
\text { Yield } \\
\text { Strength, }\end{array}$ & $\begin{array}{l}\text { Tensile } \\
\text { Ultimate } \\
\text { Strength, }\end{array}$ & $\begin{array}{r}\text { Elong } \\
0\end{array}$ & ation, & Bend \\
\hline & Temperature & & & in 1 in. & in 2 in. & Test \\
\hline TD Nickel & As Received & 75.9 & 92.0 & 12 & & $G$ \\
\hline & $1000^{\circ} \mathrm{C}$ & 76.2 & 95.5 & 14 & & $\mathrm{G}$ \\
\hline & $1200^{\circ} \mathrm{C}$ & 45.2 & 89.9 & 22 & & $\mathrm{G}$ \\
\hline Nickel 200 & As Received & 32.1 & 70.6 & 44 & & G \\
\hline & $1000^{\circ} \mathrm{C}$ & 17.7 & 61.8 & 38 & & $\mathrm{G}$ \\
\hline & $1200^{\circ} \mathrm{C}$ & 13. 9 & 62.1 & 43 & & $\mathrm{G}$ \\
\hline Hastelloy B & As Received & 53.7 & 121.8 & 52 & & $\mathrm{G}$ \\
\hline & $1000^{\circ} \mathrm{C}$ & 61.2 & 106.8 & 10 & & $\mathrm{G}$ \\
\hline & & & & & & \\
\hline Hastelloy $\mathrm{X}$ & As Received & 62.0 & 116.0 & & 34 & $\mathrm{G}$ \\
\hline & $1000^{\circ} \mathrm{C}$ & 50.0 & 63.1 & & 1 & $\mathrm{~N}$ \\
\hline & $1200^{\circ} \mathrm{C}$ & Broken & Machining & & & $\mathrm{N}$ \\
\hline Inconel 625 & As Received & 79.6 & 135.5 & & 44 & $G$ \\
\hline & $1000^{\circ} \mathrm{C}$ & 57.8 & 72.1 & & 3 & $\mathrm{~N}$ \\
\hline & $1200^{\circ} \mathrm{C}$ & Broken & Machining & & & $\mathrm{N}$ \\
\hline Inconel 600 & As Received & 39.4 & 92.6 & & 40 & $\mathrm{G}$ \\
\hline & $1000^{\circ} \mathrm{C}$ & 31.8 & 90.8 & & 19 & $\mathrm{G}$ \\
\hline & $1200^{\circ} \mathrm{C}$ & 35.7 & 40.6 & & 1 & $\mathrm{~N}$ \\
\hline Molybdenum & As Received & 86.7 & 105.1 & & 25 & $\mathrm{G}$ \\
\hline & $1000^{\circ} \mathrm{C}$ & - & 73.2 & & 43 & $\mathrm{~N}$ \\
\hline & $1200^{\circ} \mathrm{C}$ & - & 38.2 & & 0 & $\mathrm{~N}$ \\
\hline
\end{tabular}

For the bend test results, " $\mathrm{N}$ " indicates brittle failure with minor deflection $\left(<20^{\circ}\right)$, and " $\mathrm{G}$ " indicates ductile behavior $\left(180^{\circ}\right.$ bend, usually). 
TABLE IV

PROPERTIES AFTER $200 \mathrm{hr}$ EXPOSURE

IN METAL RACKS

2 in. DOWNSTREAM FROM GRAPHITE

\begin{tabular}{|c|c|c|c|c|c|c|}
\hline & Exposure & $\begin{array}{l}\text { Tensile } \\
\text { Yield } \\
\text { Strength, }\end{array}$ & $\begin{array}{l}\text { Tensile } \\
\text { Ultimate } \\
\text { Strength, }\end{array}$ & Elong & ation, & Bend \\
\hline & Temperature & $\mathrm{ksi}$ & $\mathrm{ksi}$ & in 1 in. & in 2 in. & Test \\
\hline TD Nickel & As Received & 75.9 & 92.0 & 12 & & G \\
\hline & $1000^{\circ} \mathrm{C}$ & 60.8 & 80.0 & 11 & & $\mathrm{G}$ \\
\hline & $1200^{\circ} \mathrm{C}$ & 41.1 & 76.8 & 21 & & $\mathrm{G}$ \\
\hline Nickel 200 & As Received & 32.1 & 70.6 & 44 & & $\mathrm{G}$ \\
\hline & $1000^{\circ} \mathrm{C}$ & 12.8 & 60.6 & 38 & & $\mathrm{G}$ \\
\hline & $1200^{\circ} \mathrm{C}$ & 22.8 & 45.7 & 50 & & $\mathrm{G}$ \\
\hline Hastelloy B & As Received & 53.7 & 121.8 & 52 & & $\mathrm{G}$ \\
\hline & $1000^{\circ} \mathrm{C}$ & 64.8 & 112.8 & 15 & & $\mathrm{~N}$ \\
\hline & $1200^{\circ} \mathrm{C}$ & & & & & $\mathrm{G}$ \\
\hline Hastelloy $\mathrm{X}$ & As Received & 62.0 & 116.0 & & 34 & $\mathrm{G}$ \\
\hline & $1000^{\circ} \mathrm{C}$ & 54.0 & 78.1 & & 6 & $\mathrm{~N}$ \\
\hline & $1200{ }^{\circ} \mathrm{C}$ & 44.3 & 45.0 & & 1 & $\mathrm{~N}$ \\
\hline Inconel 625 & As Received & 79.6 & 135.5 & & 44 & $\mathrm{G}$ \\
\hline & $1000^{\circ} \mathrm{C}$ & 62.5 & 106.1 & & 24 & $\mathrm{~N}$ \\
\hline & $1200^{\circ} \mathrm{C}$ & 49. 3 & 49.8 & & 1 & $\mathrm{~N}$ \\
\hline Inconel 600 & As Received & 39.4 & 92.6 & & 40 & G \\
\hline & $1000{ }^{\circ} \mathrm{C}$ & 24.8 & 81.4 & & 34 & $\mathrm{G}$ \\
\hline & $1200^{\circ} \mathrm{C}$ & 22.2 & 82.2 & & 42 & $\mathrm{G}$ \\
\hline Molybdenum & As Received & 86.7 & 105.1 & & 25 & $\mathrm{G}$ \\
\hline & $1000^{\circ} \mathrm{C}$ & & 71.9 & & 33 & $\mathrm{G}$ \\
\hline & $1200^{\circ} \mathrm{C}$ & 40.2 & 42.7 & & 1 & $\mathrm{~N}$ \\
\hline
\end{tabular}

For the bend test results, "N" indicates brittle failure with minor deflection $\left(<20^{\circ}\right)$, and " $G$ " indicates ductile behavior $\left(180^{\circ}\right.$ bend, usually). 
BNWL-92
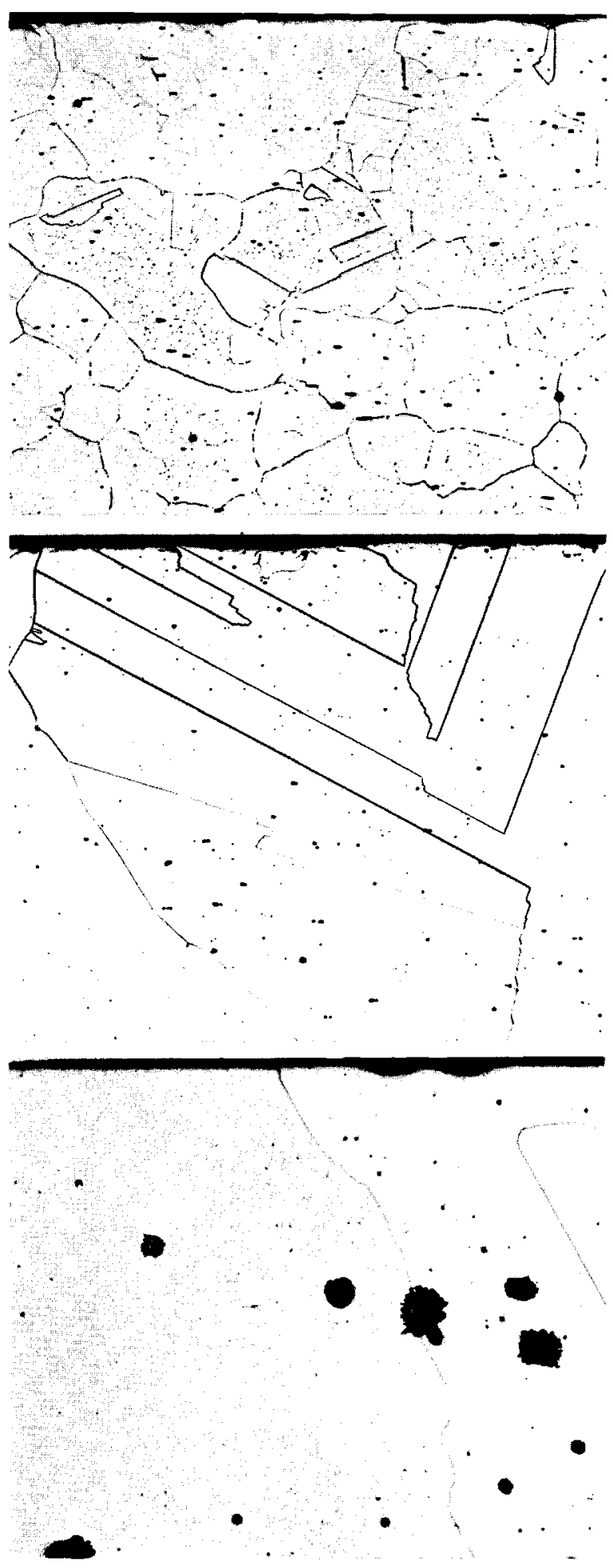

As received. All photos of microstructure include the surface of the specimen shown at the top of each picture.

After $200 \mathrm{hr}$ at $1000{ }^{\circ} \mathrm{C}$ in contact with graphite.

After $840 \mathrm{hr}$ at $1200{ }^{\circ} \mathrm{C}$ in contact with graphite. Carbon dissolved at $1200^{\circ} \mathrm{C}$ exists as graphite nodules at room temperature.

\section{FIGURE 2}

Effect of $\mathrm{N}_{2}$-Graphite Environment on $\mathrm{Ni}-200$ $100 \mathrm{X}$ 


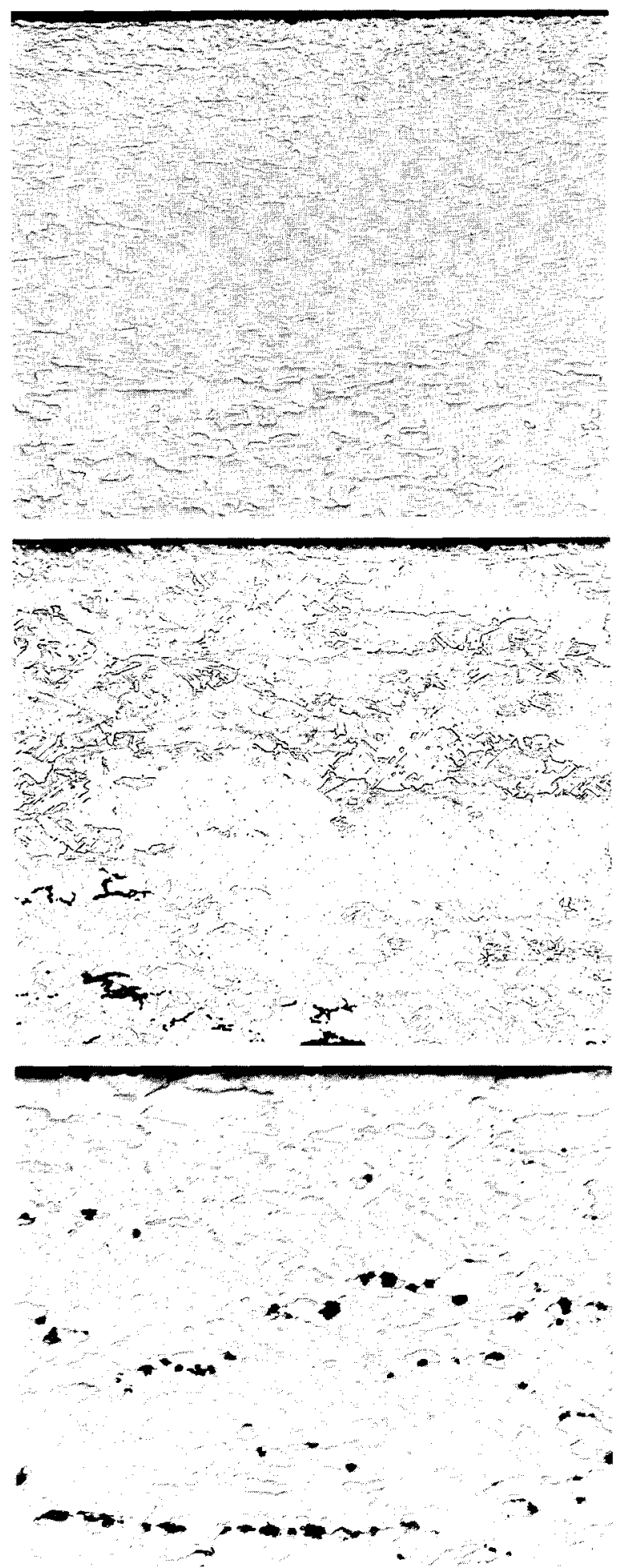

Control specimen exposed in evacuated. quartz capsule at $1200{ }^{\circ} \mathrm{C}$ for $750 \mathrm{hr}$. No observable change in the microstructure.

After $200 \mathrm{hr}$ at $1200{ }^{\circ} \mathrm{C}$ in contact with the graphite, the microstructure was nominally unchanged except for isolated patches of carbon scattered through the structure.

After $840 \mathrm{hr}$ at $1200{ }^{\circ} \mathrm{C}$, the carbon had begun to spherodize. Total carbon content similar to $200 \mathrm{hr}$ exposure specimen.

FIGURE 3

Effect of $\mathrm{N}_{2}$-Graphite Environment on TD Nickel $100 \mathrm{X}$ 

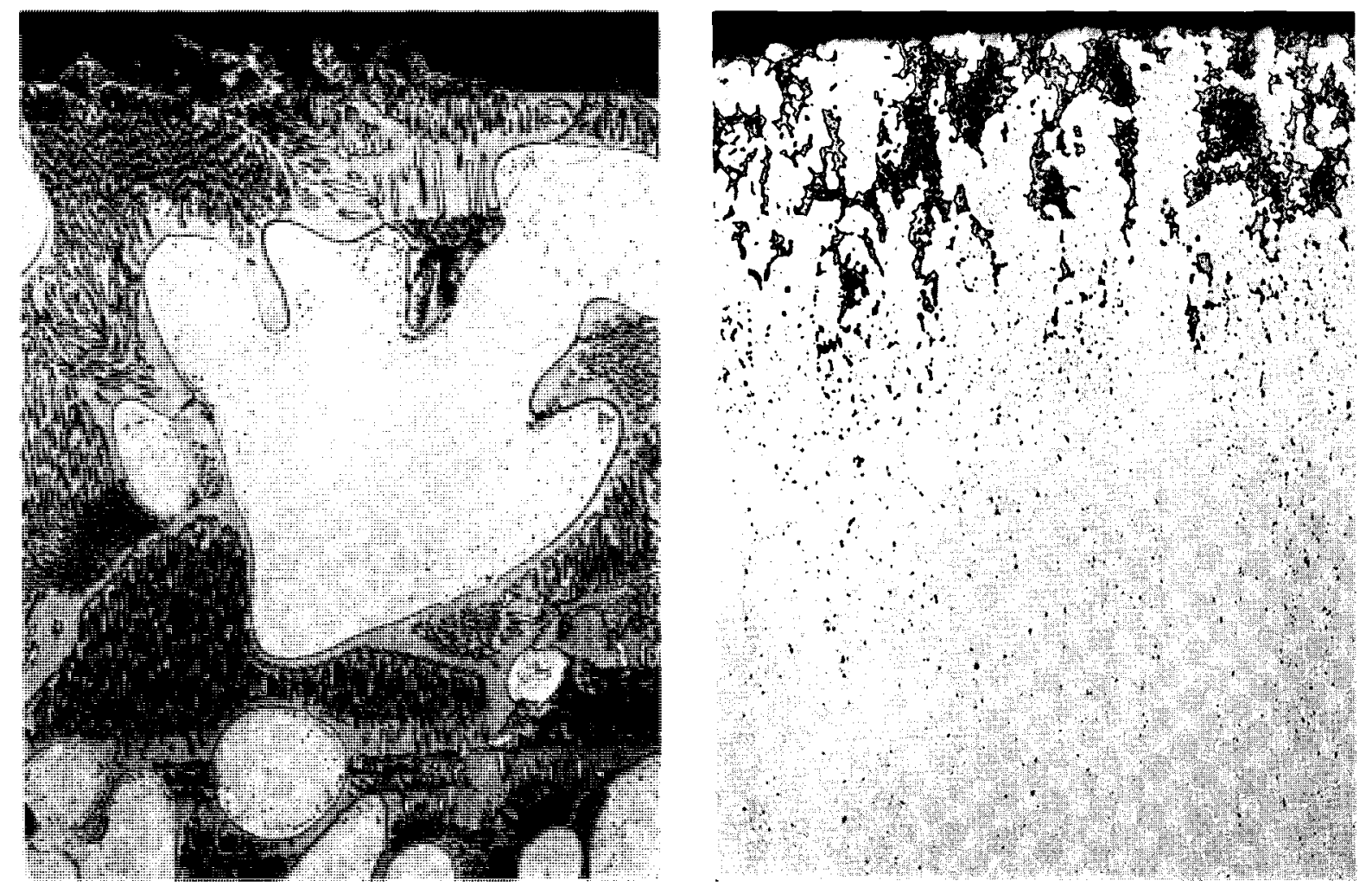

FIGURE 4

$\mathrm{Ni}-200$ (left) and TD Nickel after $75 \mathrm{hr}$ at $1200{ }^{\circ} \mathrm{C}$ in the Simulated Reactor Atmosphere and in Contact with $\mathrm{K}^{23}$ Refractory Brick $100 \mathrm{X}$ 


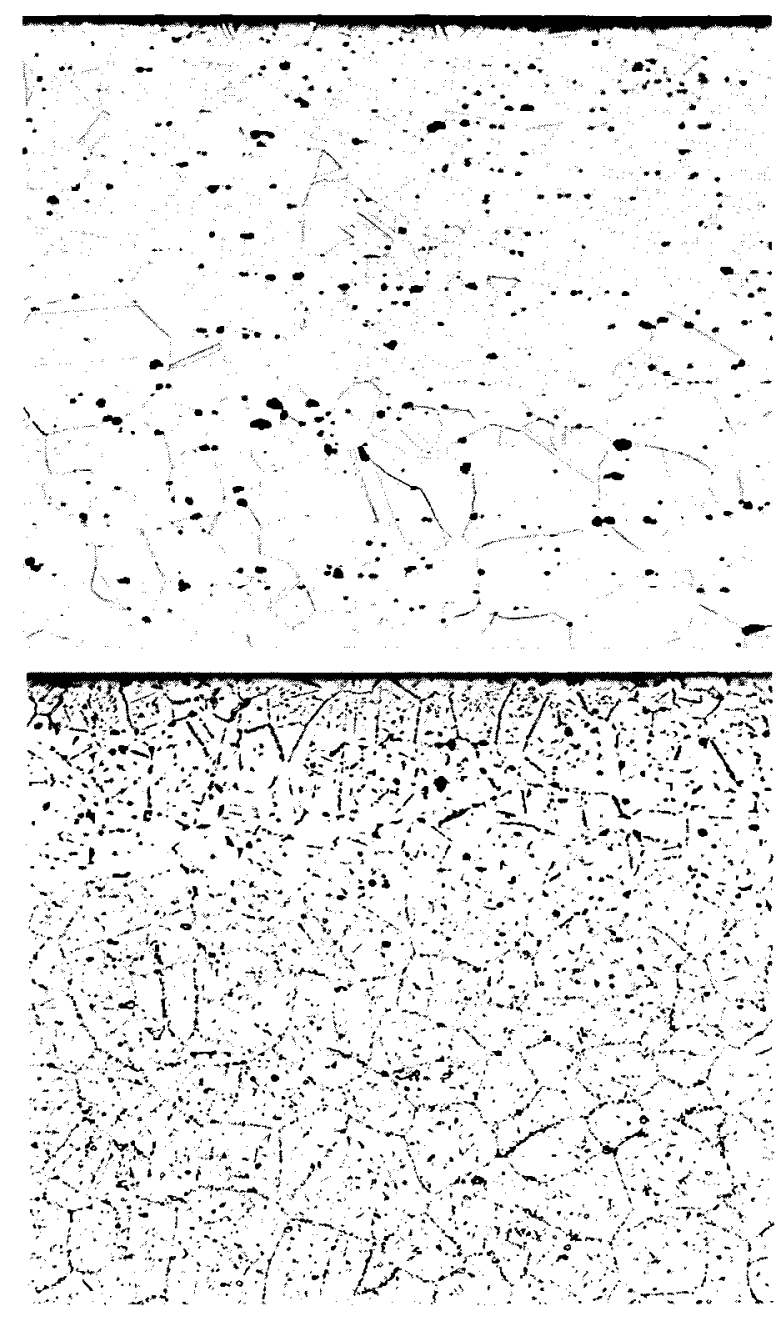

As Received.

After $200 \mathrm{hr}$ at $1000{ }^{\circ} \mathrm{C}$ in contact with the graphite.

After $200 \mathrm{hr}$ at $1200{ }^{\circ} \mathrm{C}$ in contact with the graphite.

FIGURE 5

Effect of $\mathrm{N}_{2}$-Graphite Environment on Hastelloy B 100X 
BNWL-92

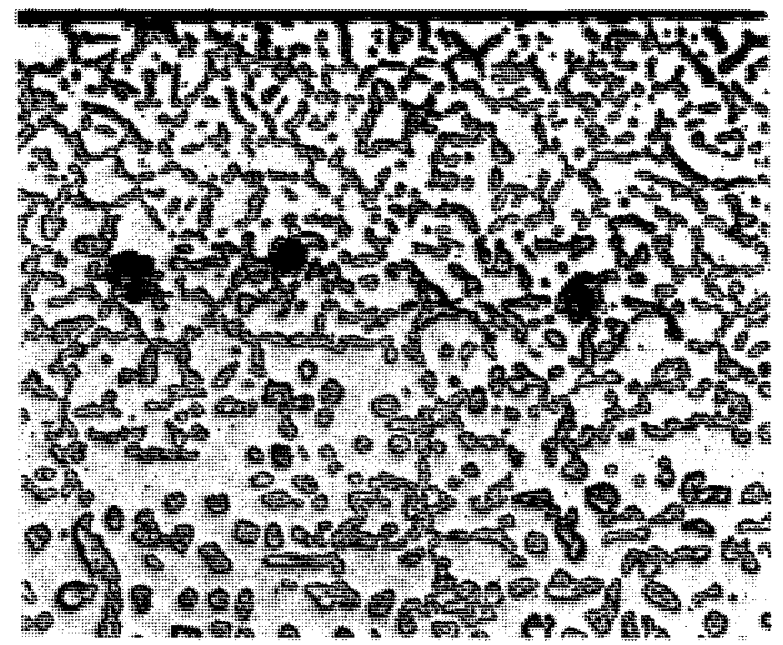

After $840 \mathrm{hr}$ at $1200{ }^{\circ} \mathrm{C}$ in contact with graphite. Apparently sufficient time had elapsed for complete carburization of one constituent, probably molybdenum, since free graphite exists.

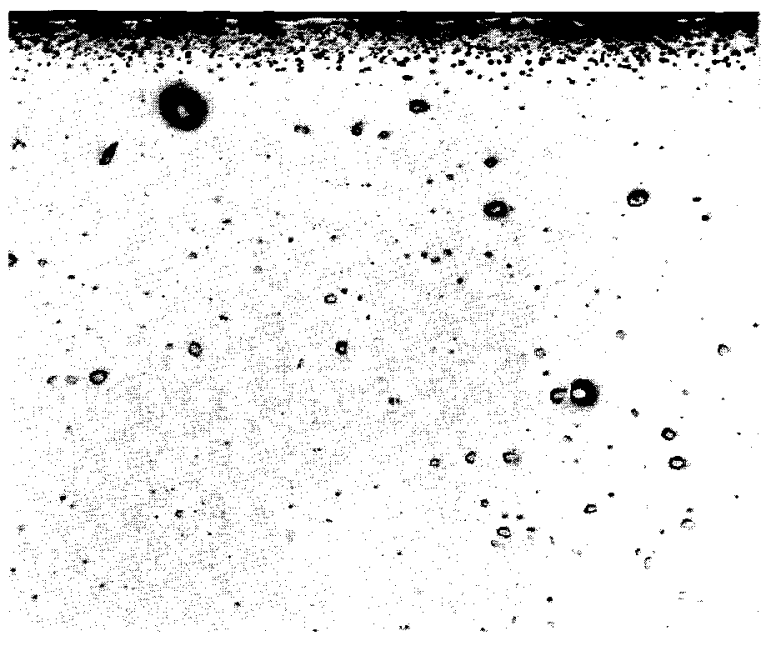

Control specimen exposed in evacuated quartz capsule at $1200{ }^{\circ} \mathrm{C}$ for $750 \mathrm{hr}$.

$\underline{\text { FIGURE } 6}$

Effect of $\mathrm{N}_{2}$-Graphite Environment on Hastelloy B (Continued from Figure 4) $100 \mathrm{X}$ 

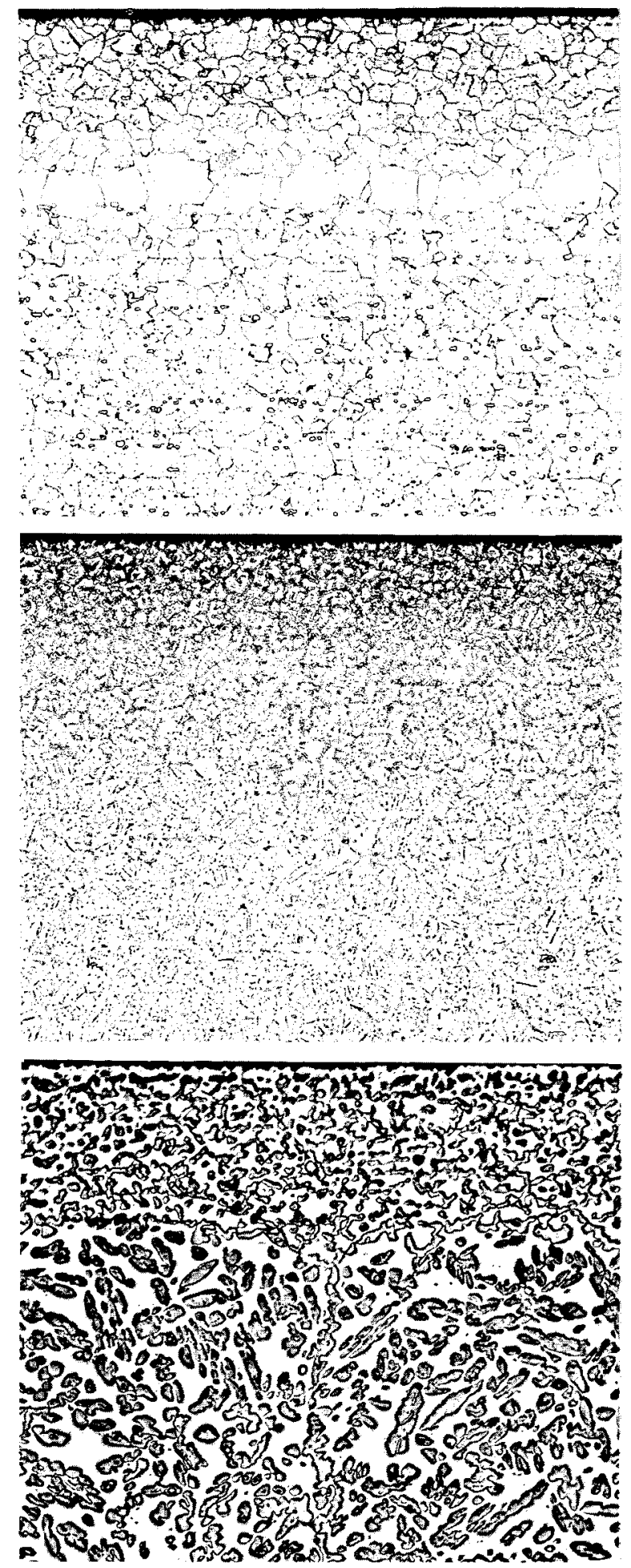

FIGURE ?

Effect of $\mathrm{N}_{2}$-Graphite Environment on Hastelloy $\mathrm{X}$ 100X graphite at $1200{ }^{\circ} \mathrm{C}$.
As received.

After $200 \mathrm{hr}$ in contact with graphite at $1000{ }^{\circ} \mathrm{C}$.

After $200 \mathrm{hr}$ in contact with 

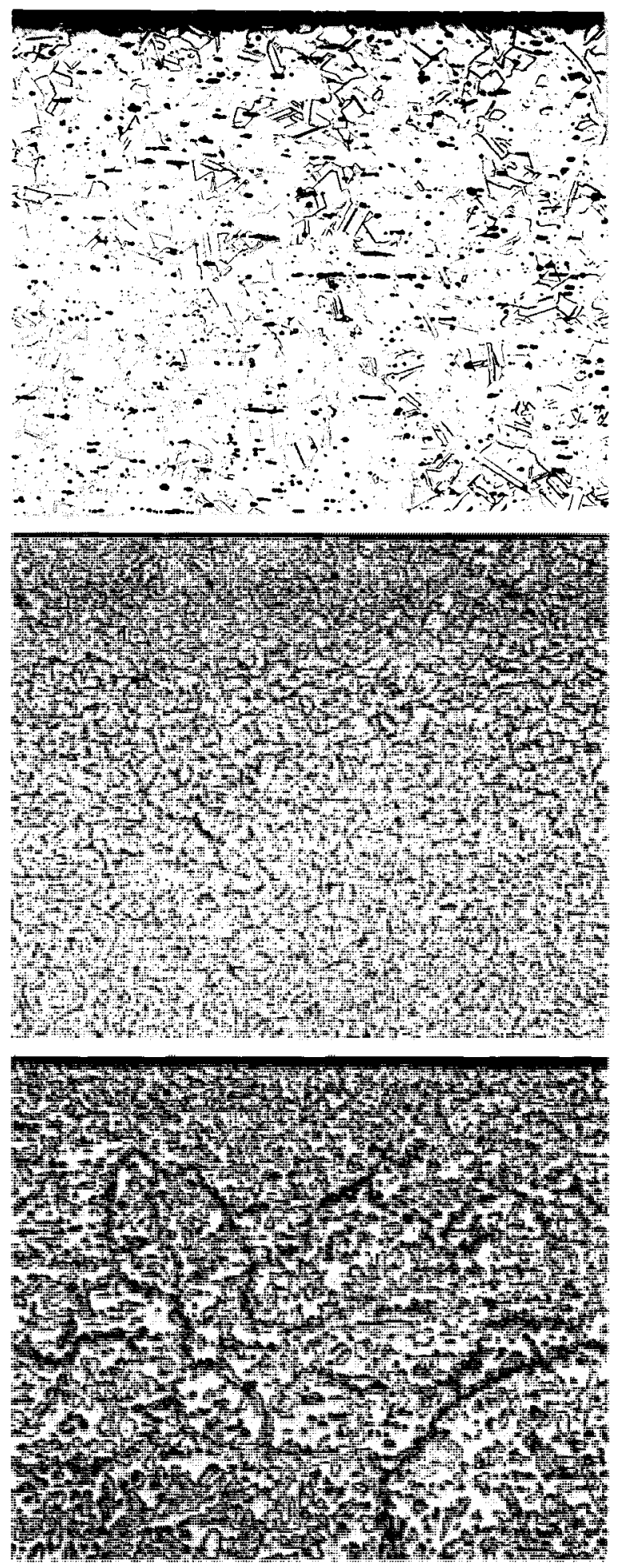

As received.

\author{
After $200 \mathrm{hr}$ in contact with \\ graphite at $1000^{\circ} \mathrm{C}$.
}

After $200 \mathrm{hr}$ in contact with graphite at $1200{ }^{\circ} \mathrm{C}$.

FIGURE 8 Effect of $\mathrm{N}_{2}$-Graphite Environment on Inconel 625 


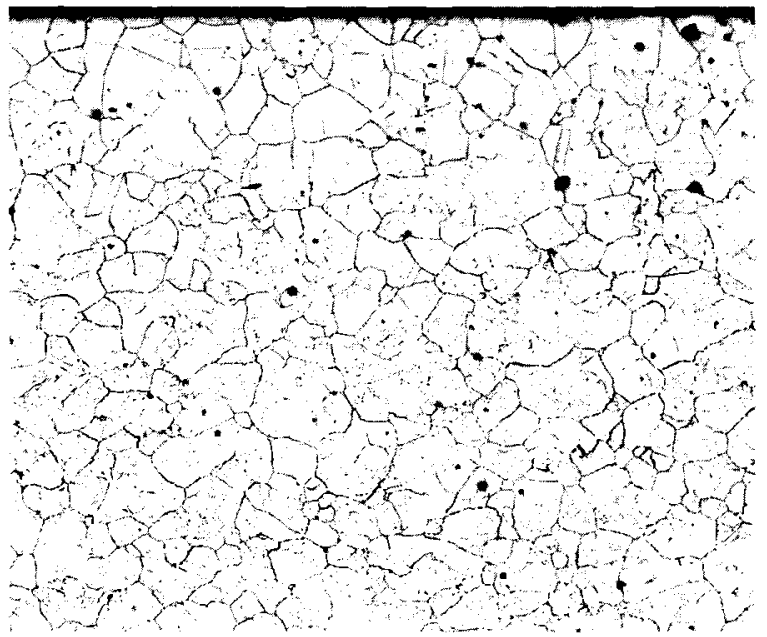

As received.

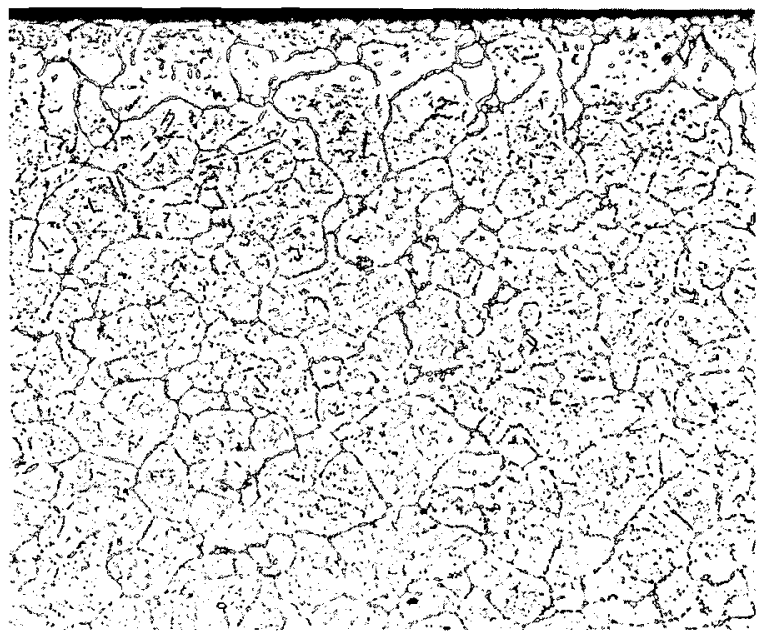

After $200 \mathrm{hr}$ in contact with graphite at $1000^{\circ} \mathrm{C}$.

FIGURE 9

Effect of $\mathrm{N}_{2}$-Graphite Environment on Inconel 600 $100 \mathrm{X}$ 

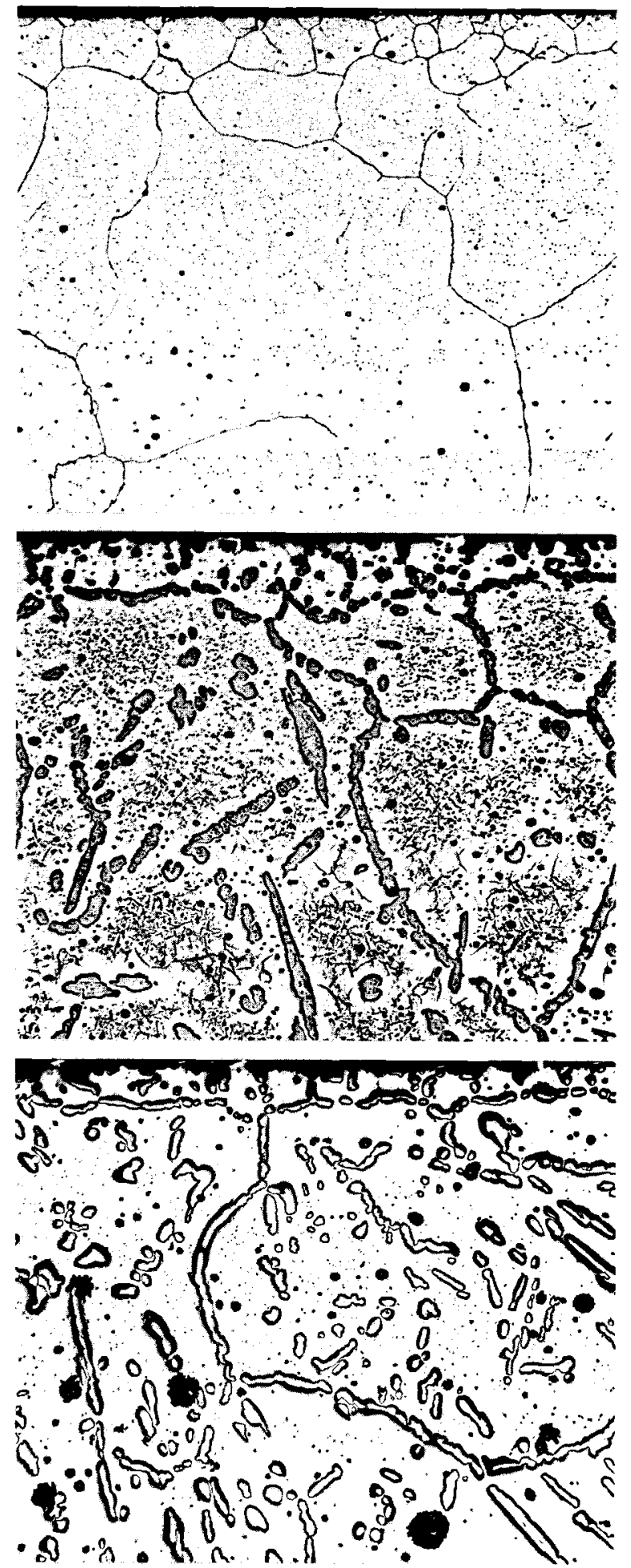

After $200 \mathrm{hr}$ at $1200{ }^{\circ} \mathrm{C}$ in the simulated reactor atmosphere, but held in the metal rack out of contact with the graphite.

\begin{abstract}
After $200 \mathrm{hr}$ at $1200{ }^{\circ} \mathrm{C}$ in contact with graphite.
\end{abstract}

After $840 \mathrm{hr}$ at $1200{ }^{\circ} \mathrm{C}$ in contact with graphite.

\section{FIGURE 10}

Effect of $\mathrm{N}_{2}$-Graphite Environment on Inconel 600 (Continued from Figure 8 ) 

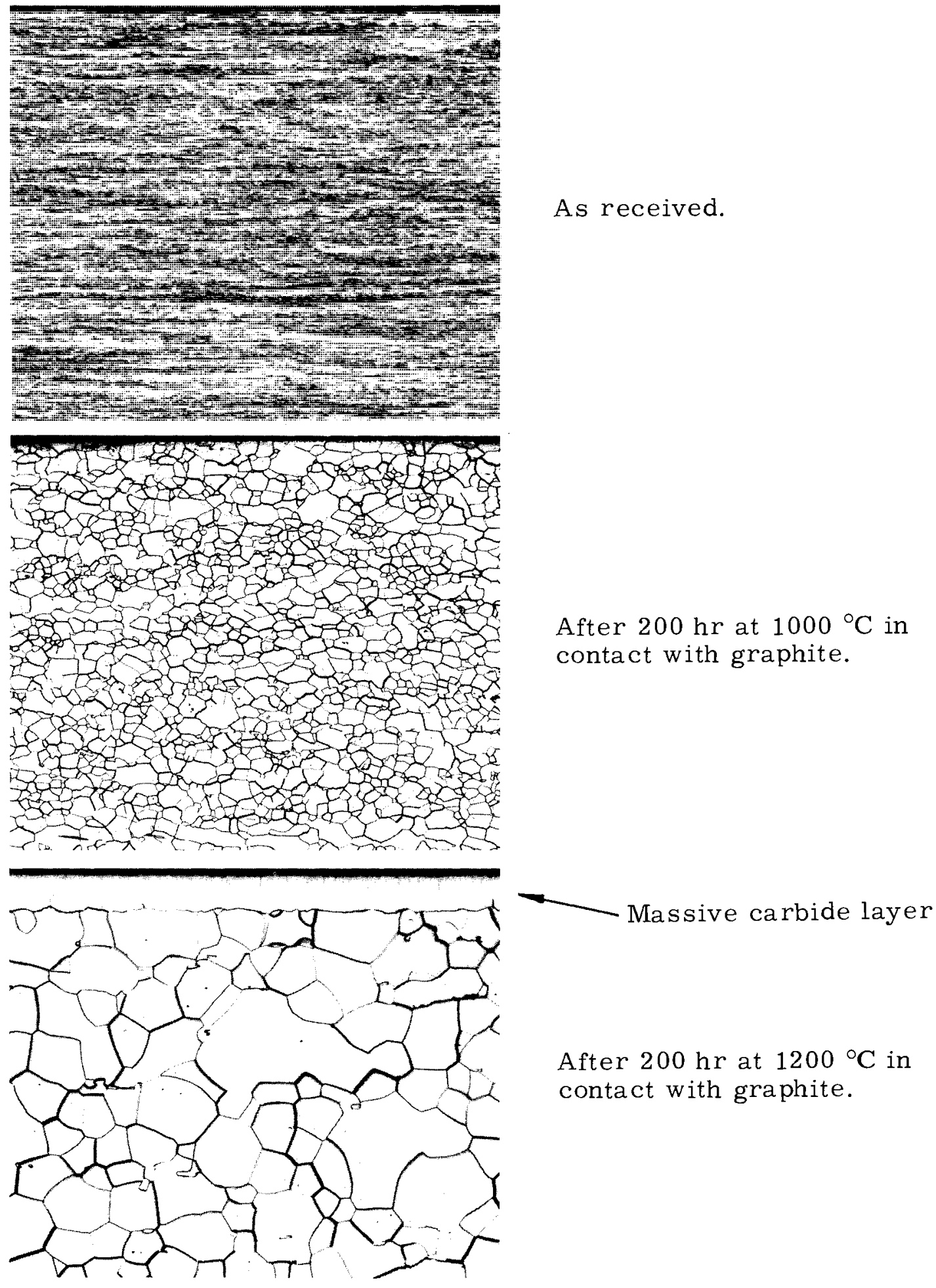

FIGURE 11

Effect of $\mathrm{N}_{2}$-Graphite Environment on Molybdenum
After $200 \mathrm{hr}$ at $1000{ }^{\circ} \mathrm{C}$ in contact with graphite.$$
\text { contact with graphite. }
$$

After $200 \mathrm{hr}$ at $1200{ }^{\circ} \mathrm{C}$ in contact with graphite.
As received. 

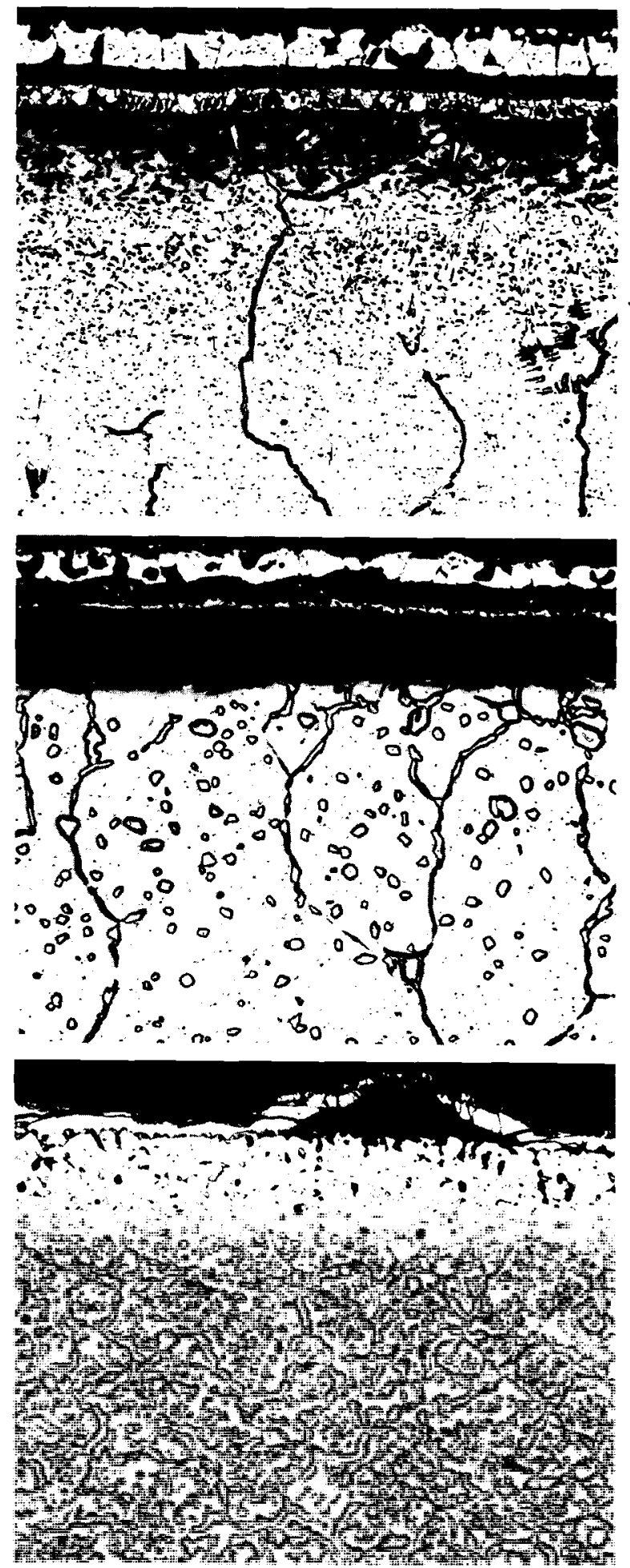

FIGURE 12

Hastelloy $\mathrm{X}$ with Commercial Coatings as Indicated after $75 \mathrm{hr}$ at $1200{ }^{\circ} \mathrm{C}$ in $\mathrm{N}_{2}$-Graphite Environment $100 X$
Sola $r$ aluminized.

Arthur tickle aluminized.

Solar S6100 coating (ceramic). 


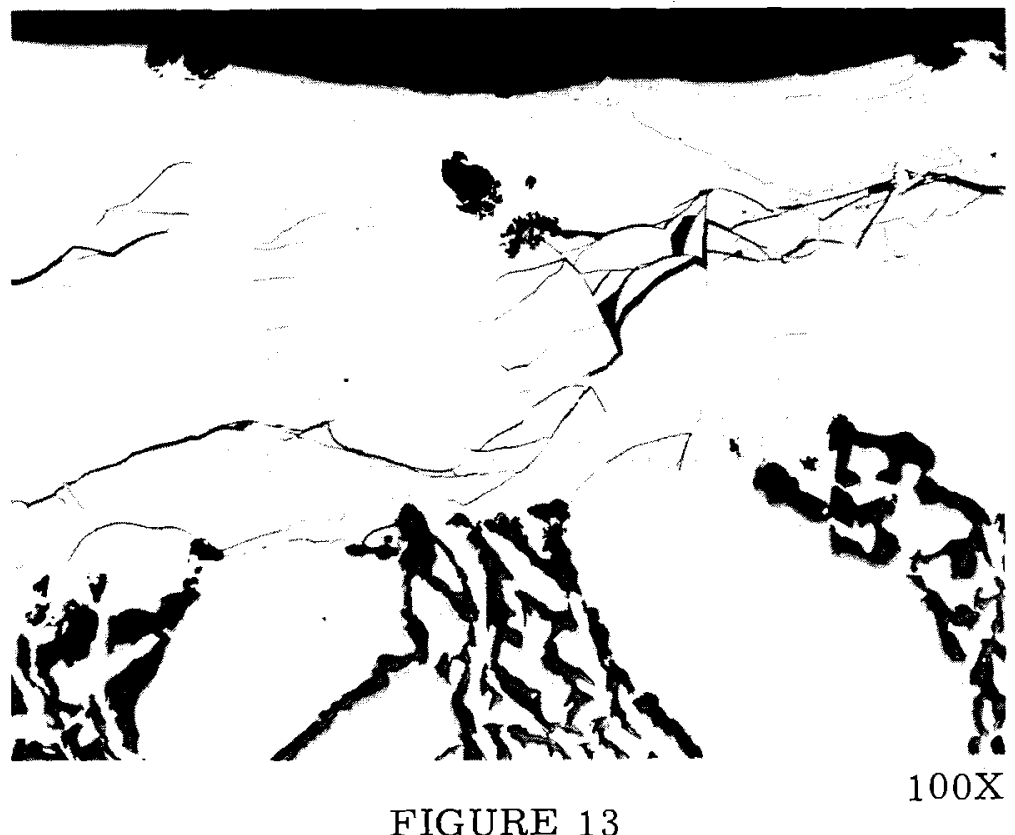

Structure Resulting from Reaction of $\mathrm{UO}_{2}$ with Nickel Container

(Surface shown was in contact with $\mathrm{UO}_{2}$. The container was open to the $\mathrm{N}_{2}$ - $\mathrm{CO}$ atmosphere. Exposure was at $1200^{\circ} \mathrm{C}$ for $74 \mathrm{hr}$.)

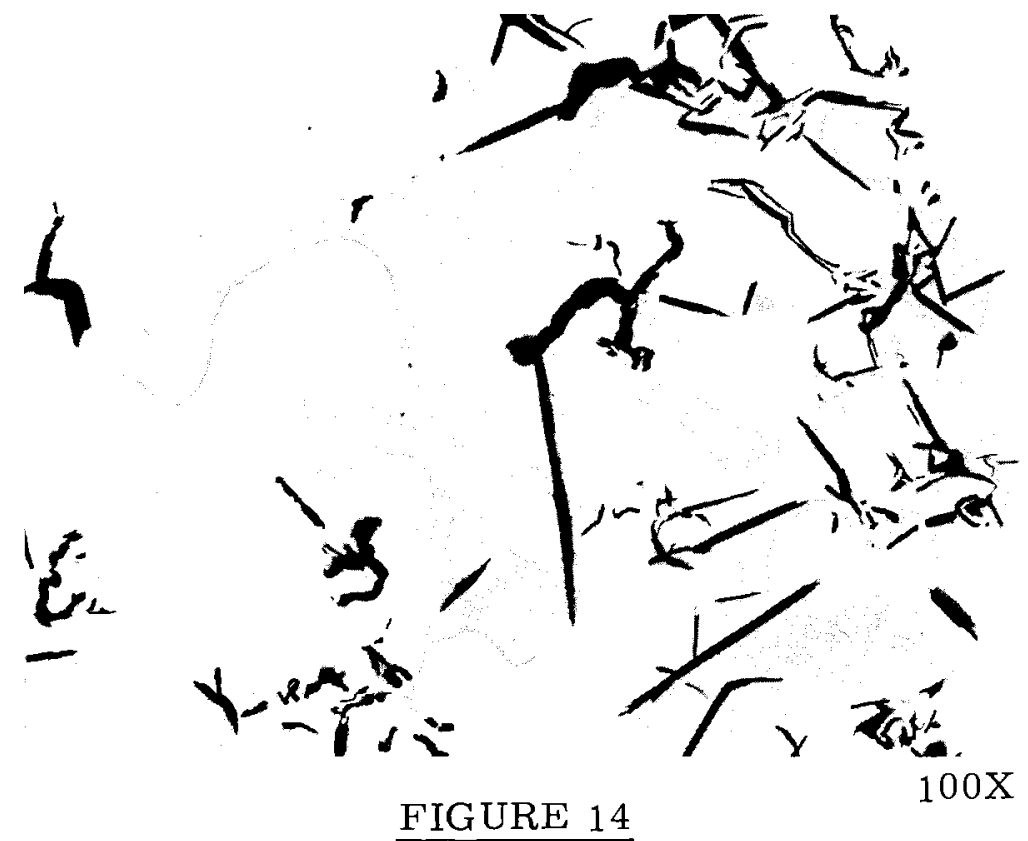

Reaction Product of $\mathrm{B}_{4} \mathrm{C}$ with Nickel Container (Container was evacuated and sealed before exposure at $1200^{\circ} \mathrm{C}$ for $75 \mathrm{hr}$. This alloy was molten at the test temperature.) 


\section{ONSITE DISTRIBUTION}

\section{Copy Number}

1

$2-6$

7

8-13

14

15

16

17

18

19

20

21

22

23

24

25

26

$27-32$

33

34

35

36

37

38

39

$40-44$

45

46

47

48
Pacific Northwest Laboratory

F. W. Albaugh

D. Ballard

A. L. Bement

W. W. Brown

S. H. Bush

R. G. Clark

F. G. Dawson, Jr.

R. L. Dillon

K. Drumheller

R. E. Heineman

R. J. Hoch

R. M. Humes

M. R. Kreiter

G. A. Last

J. E. Minor

B. L. Morgan

R. E. Nightingale

D. P. O'Keefe

D. E. Rasmussen

D. P. Schively

R. E. Westerman

R. G. Wheeler

O. J. Wick

R. E. Woodley

E. M. Woodruff

Technical Information Files

Technical Publications-300 Area

Technical Publications-700 Area

Richland Operations Office

R. K. Sharp

Technical Information Library 